\title{
Peatmoss Derived Biochar as an Effective Sorbent for Removing VOCs in Groundwaters
}

\author{
Jeonggwan Kim \\ Korea Environmental Industry \& Technology Institute \\ 215, Jinheung-ro, Eunpyeong-gu, Seoul, Republic of Korea, jgwan@keiti.re.kr
}

\section{Extended Abstract}

Peatmoss derived biochars were produced at the pyrolytic temperatures of 300,500 , and $700{ }^{\circ} \mathrm{C}$ and were tested for the effectiveness of VOCs removal in waters. As the pyrolytic temperature increases, the carbon content were increased from $66 \%$ to $84 \%$ and hydrogen and oxygen contents were decreased from $4 \%$ to $1 \%$ and $19 \%$ to $4 \%$, respectively. The surface areas of the biochars were $2 \mathrm{~m}^{2} / \mathrm{g}$ at the pyrolysis temperature of $300{ }^{\circ} \mathrm{C}$, and were increased to 200 and $300 \mathrm{~m}^{2} / \mathrm{g}$ at 500 and $700{ }^{\circ} \mathrm{C}$. FT-IR analysis showed that functional groups such as hydroxyl, nitro, and carboxyl groups were present at biochar produced at $300{ }^{\circ} \mathrm{C}$, however, the functional groups were removed in the biochars produced at higher temperatures.

Sorption kinetics and equilibrium experiments were conducted with 6 selected VOCs, such as benzene (BZN), toluene (TOL), ethylbenzene (EBZ), p-xylene (pXYL), trichloroethylene (TCE), and tetrachloroethylene (PCE), which are the most common VOCs found in contaminated groundwater of South Korea. Sorption equilibrium was attained within 6 hrs with first order kinetic rate constants of $0.5 \mathrm{hr}^{-1}$ for the VOCs tested. Biochar produced at $500{ }^{\circ} \mathrm{C}$ showed the highest sorption capacity for all VOCs, although biochars produced at 300 and $700{ }^{\circ} \mathrm{C}$ showed similar sorption capacity.

The biochars produced at $500{ }^{\circ} \mathrm{C}$ were tested on actual TCE contaminated groundwater and showed an excellent removal efficiencies both in batch and column experiments.

\section{References}

[1] M. Ahmad, A. U. Rajapaksha, J. E. Lim, M. Zhang, N. Bolan, D. Mohan, M. Vithanage, S. S. Lee, and Y. S. Ok, "Biochar as a sorbent for contaminant management in soil and water: a review," Chemosphere, vol. 99, pp. 19-33, 2014.

[2] S. Babel, T. A. Kurniawan, "Low-cost adsorbents for heavy metals uptake from contaminated water: a review," Journal of Hazardous Materials, vol. 97, pp. 219-43, 2003.

[3] L. Beesley, E. Moreno-Jimenez, J. L. Gomez-Eyles, E. Harris, B. Robinson, T. Sizmur, “A review of biochars' potential role in the remediation, revegetation and restoration of contaminated soils," Environmental Pollution, vol. 159, pp. 3269-82, 2011.

[4] J. S. Cha, S. H. Park, S. C. Jung, C. Ryu, J. K. Jeon, M. C. Shin, Y. K. Park, "Production and utilization of biochar: A review," Journal of Industrial and Engineering Chemistry, vol. 40, pp. 1-15, 2016

[5] S. Wang, C. Zhao, R. Shan, Y. Wang, H. Yuan, "A novel peat biochar supported catalyst for the transesterification reaction," Energy Conversion and Management, vol. 139, p. 89, 2017. 